\title{
An Examination of the Stakeholder Involvement as a Democratic Effort to Link University Education to Industry Expectations - A Case of Zimbabwe
}

\author{
${ }^{1}$ Sithobile Priscilla Dube, ${ }^{2}$ Yusef Waghid, ${ }^{3}$ Tomson Dube, ${ }^{4}$ Timothy Luzane \\ ${ }^{1,3,4}$ National University of Science \& Technology \\ (NUST), Zimbabwe \\ ${ }^{2}$ Stellenbosch University, South Africa
}

\begin{abstract}
My research focuses on elaborating on the experiences of twenty participants during their studentship and their transition into employment. The major concern is to find out whether university programmes are tailored to produce graduates that are employable, well identified and suitable for the industry. The purpose is also to collect views on whether stakeholder involvement is a democratic effort to link Zimbabwean university education to industry expectations. The research was conducted using a qualitative interpretive approach and in-depth interviews with students, graduates and industry managers. Analytic induction was used to uncover categories and themes in the data set. The issue of democracy was pursued in order to determine whether there existed democracy in the planning and development of university programmes. The findings revealed that there was need for dialogue and collaboration amongst the various stakeholders. The universities are expected to provide valuable programmes for the whole-person development support in order to make the transition into employment and job creation opportunities possible. There exists a notion that the gap is caused by the lack of support by the universities and the industry to bridge this gap through creation of programmes to support the students' training and development up to graduation level (200 words).
\end{abstract}

\section{Introduction}

The issue of graduate employability has been appearing high on the agenda of higher education, government, universities, and industries on the media and literary publications (Mawere [11] and Makoshori [9]). The employers and employees, graduates, students, parents and other stakeholders cry foul over what they see as a gap existing between the graduation period of university students and their entry into the world of work. There arises a greater need for the examination of the role of universities and the industries to agree on how they can work together to produce graduates who are skilled enough to contribute to meeting the challenges of the economy considering that there are other factors that could affect the condition of the economy of a country. The various arguments throughout this study and the discussions of the results in the data collected seem to exert the pressure not only on universities to produce employable graduates. The arguments also pose a greater responsibility on the employers to give an input on how to handle the complicated transitions in the journey of graduates during and after their period of study. The writers Archer \& Davison (2008) and Cranmer in Lowden [8] all found out that there is a contrast between what some universities are promoting and what is required by industry as evidenced by their failure to implement their strategic plans. The writers further discovered that there are concerns from some academics about employability measures in their universities diminishing the academic integrity of higher education provision. There is also frustration from employers about courses not meeting their needs. However, according to Lowden [8] there appears to be no fundamental reason why institutions and employers cannot reach a consensus on educational approaches that promote employability. There have been developments in government policy to encourage higher education institutions and employers to work together to develop approaches to training and preparing students for employability. However, there are still issues and barriers between employers and many of those responsible for policy, particularly in terms of differences in mindsets, expectations and priorities.

\section{Statement of the Problem}

The problem is that the Zimbabwean industry is suffering from receiving graduate workers that do not display the scientific, technological, social, problemsolving and creative skills as expected on the market. The training needs of the industry are not met by universities and the recommendation is that the industry should be involved in assessing university programmes and courses to ensure that the required skills are being imparted. In order to bring 
transformation in the higher education institutions, industry, individuals and the country as a whole there is need to create a synergy where all stakeholders could be re-engaged in the redesigning of the curricula in order to solve problems. The engagement is hoped to bring a lasting change and refined relevant education policies.

\section{Research Aims}

Whereas in the past it has been common practice for universities to independently churn out graduates without the input of all stakeholders involved in education, training and in the world of work, the modern trend requires a holistic approach. In this paper, the process of examining how the stakeholder involvement can be a democratic effort to link university education to industry expectations was determined.

\section{Research Objective}

The study was guided by the following research objective:-

To identify and examine the effects of the stakeholder involvement as a democratic effort to link university education to industry expectations.

\section{Research Question}

To what extent does stakeholder involvement achieve to be a democratic effort to link university education to industry expectations in issues of employability?

\section{Research Methodology}

The study adopted a mixed approach of qualitative and quantitative also known as interpretive. The interpretive research approach emerged from the works of philosophers like Kant, Hegel and Brentano [3] and Van Der Wal DM [15]. It explored, described and understood people's everyday experiences and appearances of things in their minds [1], [2]. These experiences were not just described but were interpreted so that as a researcher I could arrive at a deeper understanding of these experiences and this led me to come up with knowledge and recommendations to address the needs of the community. The interpretive qualitative inquiry involved analyzing and understanding. A deliberate case study framework was employed and data was gathered from the target population of state universities, graduates and industries in Zimbabwe. An exploratory case study is better understood in interpretivism with cases that had same beliefs in education policies and were representative of key valuable informants [4] and Gray [7]. The cases also had variables that tend to influence the selection decisions and depend on each other as observed by Creswell [3]. The individuals involved were key decision makers and had information that ordinary people would not have in the selected cities of Harare, Bulawayo, Gweru, Masvingo and Lupane in Zimbabwe.

The research data collecting tool that was employed in this study was an interview using structured in-depth interviews using an interview guide. The objective was to promote better selfunderstanding and increase insight into the human condition. Facts about human behaviour were also collected that led to verification and extension of theories and emphasis was also on the improved understanding of human behaviour and experience [3]. The collection of information through interviews helped me to interpret the knowledge collected versus prior knowledge and understanding of the researcher. As a researcher I worked with the participants and interacted to shape and to be open to one another. I exercised 'empathy' and 'reflexivity' avoiding as much as possible preconceptions during the process of data collection and analysis confirming what Creswell [3], Van Manen [16] and Van Der Wal DM [15] say. Twenty participants were selected through purposive and snowballing sampling procedures. The targeted participants were selected from the selected four universities: National University of Science and Technology (NUST) in Bulawayo, Lupane State University (LSU) in Lupane, Midlands State University (MSU) in Gweru and Great Zimbabwe University (GZU) in Masvingo and industries in those cities. The cities were the most productive, major commercial and industrial centres.

The samples were from the diversity of all the selected universities and industries by virtue of their portfolio levels as students and graduates. Managers in each industry included both senior management and middle-management and employees with varying levels of education and experience. These were sampled for the sole purpose that they would provide the answers to research objectives set out to be researched.

Purposive sampling represents participants who are known or judged to be good sources of information and are specifically sought out and selected for the sample. I chose the method after putting into consideration of what Grady [6] say that purposeful sampling is the most important guiding principle as maximum variation. This means that researchers should seek to include people who represent the widest variety of perspectives possible within the range specified by their purpose. According to Mason [10] and Denscombe [4] snowball sampling is the form of sampling where the researcher identifies a small number of individuals with the characteristics that are required (postgraduate students studying at a university, university and 
industry managers). Therefore, using the initial sample the researcher was led to other respondents about whom the researcher knew little about.

\section{Data Collection and Analysis}

During the interview notes were taken and audiorecording was conducted then the data was transcribed. Transcripts were analyzed in order to integrate themes and concepts into a theory. The theory offered an accurate, detailed but subtle interpretation of the research field [4], Mason [10] and Grady [6]. NVivo Version 20 was used to determine the frequency of themes in the interviews and show the dominant themes. The analysis was used to interpret recommendations and knowledge for policy makers.

\section{Literature Review}

\subsection{Introduction}

This section briefly outlines some of the perceptions of researchers regarding the connection between graduation and work in industry with a focus on reviewing democratic activities in university education and their effects on employment issues. Much emphasis is put on the function of universities and their involvement of stakeholders which is considered as a democratic activity in education in order to bring about lasting change in the economy of the country. This section seeks to ascertain whether the advent of democracy in Zimbabwe education has had a positive or a negative relationship between graduation and employment.

\subsection{Stakeholders Involvement as Government's Democratic Efforts to Resuscitate the Economy}

One of the greatest efforts has been to involve the stake holders since the inception of the new government on 21 November 2017 in order to promote education that creates employability and also to resuscitate the economy. The approach of this section would be to present arguments in defence of DCE whose aim is to promote stake holder involvement in education and employability issues. I chose to adopt Waghid (2010)'s approach of DCE in his nine-chapter book and would show how the government efforts of involving stakeholders are linked to the approach. In these nine chapters DCE is described as a process of belligerence, deliberation and belonging, feelings of compassion in considering education issues, friendships, respect and forgiveness, justice, avoidance of violence and extremism, Ubuntu (I am because we are), education transformation/change and encounter with self. The government efforts to hold an education conference in 2018 where a democratic effort of stakeholder consultation is discussed in the following paragraph.

A spontaneous reaction of the people of Zimbabwe was reported by the Minister of Higher and Tertiary Education, Murwira [13] that government efforts were to do the following; promote external trade and engage Zimbabwean diaspora which was a new regime thrust. This new era of diplomatic reengagement was envisaged in making Zimbabwe a potential new and indigenous business destination. The country would be a destination for investors and tourists. The international portfolio would now include a new mandate to attract foreign investors and revisit previous engagements. New business projects through ease of business were being introduced. The intention was to create jobs using diaspora strategies where the diasporas were encouraged to invest in their country. They were re-attracted to come and invest in their country and their being in the diaspora meant they were first ambassadors in those countries. The intention was to improve employability through job creation thus improve the economy by rejoining the commonwealth. These government efforts were in line with earlier recommendations by Shizha \& Kariwo [14] who encouraged privatization and engagement of foreign countries in order to engage in efforts to revive the economy.

Stakeholder involvement was seen when the government met to discuss with different groups on how to improve the economy, education facilities and how to improve on issues of employability. Such a meeting was held with university leaders, students, local and foreign funders from November 2017 to March 2018.These consultations with stake holders according to Waghid \& Davids [20] are a way of helping individuals to act democratically and to encourage people to engage deliberately with each other. Openness to deliberation is encouraged and individuals have equality to speak and develop a sense of belonging. The aspects of "co-belonging" and "internal inclusion" as emphasized by Waghid \& Davids [20] helps individuals not to be internally excluded but they are allowed to engage in deliberate arguments freely expressing their thoughts. This cobelonging does not only allow for expressions of problems but it could mean allowing people to choose self-exclusion to allow them to heal from hatred and traumatic experiences. They might have gone through the traumas until at a time they can [20]. This is a process of allowing people to disclose and lay bare their feelings of anger and resentment and in the long run can contribute towards eradication or minimization of perpetual problems at home, work or the community.

On his introduction message first ever conference in Zimbabwe on 10 March 2018 in Harare the Minister of Higher Education, Murwira [13] mentioned that university students were expected to 
produce goods and services at the end. The universities' target was to train students adequately so that they become specialists just as the curriculum had intended to produce economists, politicians, scientists, mathematicians, engineers, etc. The graduates would be expected to set spin off industries. The government was targeting to build university towns where industries would be constructed around the universities and jobs would be readily available for students and graduates thus solving the employability issue. The Minister was promising engagement into education transformation and change by the universities which Waghid [18] confirms that it is a contribution to DCE. This is the process when one begins to see and allows individuals to be openminded and connect with others. In this case the government and universities connecting with students for peace building against conflicts. Connections are also for creation of jobs versus the high employment rate as a cry from graduates and unemployability of graduates that industry complains about. The university student representatives were present in the first ever investment conference and they expressed their gratitude for being given an opportunity to air their views in the presence of the head of the state [13]. The students also viewed education as capital and, therefore, pleaded with the government to assist in completing to build infrastructure for their lecture rooms, laboratories and sporting facilities. A plea for special facilities to be provided for the physically challenged was made. More importantly was their request for further and continuous meetings with the largest population of students of which they were assured that their request will be attended to.

In such an instance where the students were engaged in the deliberations, DCE is possible as seen by Waghid [18] who confirm that Ubuntu, some form of communal engagement was fulfilled. This promotion of Ubuntu allowed space for all stakeholders including students themselves who would be able to articulate themselves and were being freed from domination. The human relations were ensured to flourish and respect for each other became evident. The government and universities were willing to work with students irrespective of their vulnerabilities. The purpose of the meeting, giving room for deliberations and taking time to hear from each other of what would be good for them became a democratic way of working at changing their situations. The purpose would be to help universities to assist students to be prepared enough to face the world of work. Students feel treated as free and equal citizens to the politicians and university administration. Injustice and inhumanity become history of the past. DCE involves individuals to know that they have civil political and social rights to freedom of speech. They can also give an account of their reasons in order to support or disagree with any point of view and can merely listen to other points of view. According to Waghid [18], such an opportunity given to people in a conference of this nature with students, government officials and universities provides education that allows people to see life that promotes democracy and citizenship to be more explicit. In order to be more explicit, Waghid [18] sees such an experience as compassionate imagining which involves treating justly and humanly students and graduates who are faced with matters of concern, for example job discrimination, unemployment, abuse of women, poverty, political alienation, absence of good prospects and promotion, underemployment, etc. The list can be endless.

The judgment of the situation is based on graduates and students' distressed undeserved misfortune, suffering and injustice. Compassion gets called for among the other members in the stakeholders' meeting and it encourages them to be aware of the misfortunes of the vulnerable students and graduates who have been victims of unemployment. The other stakeholders can see that it is never the fault of the government or universities. The students, graduates and universities should be full of compassion and be aware that the country of Zimbabwe did not even deserve to suffer from the high rate of unemployment recorded to read $95 \%$ by the World Bank (2018) in Murwira [13]. The call by Waghid [18] is to engage in compassionate imagining and discussion and have a hope of suggesting improvements. All should see the need to find creative ways of helping from an emphatic point of view thus engaging in the deliverance argumentation involving compassion. On the same education conference in his speech and response to the student body, Mnangagwa [12] displayed the democratic qualities of compassion, friendship, respect and forgiveness as alluded to by Waghid [18]. He mentioned that he had earned potential investors previously produced by universities and was in this meeting engaging in deliberations with academics, graduates and students.

The universities were working towards producing well-rounded employable college graduates for the global market. This was a process of sustaining Development Goal number 4 with the initiative to support university institutions in order to make them successful. The objective is also to call for foreign investors to be involved through private public partnerships. The investors are welcome in the country to boost universities through the "open policy" for business. The institutions have been growing. The stagnant development has been due to little or no resource for a long time. Mnangagwa [12] mentioned that the models in the banks have been put in place to promote education through loans that are made available for students. There has also been government calls for scholarships for university and college students. The effort has been to serve 151380 students from colleges, universities and institutions. 
During his meeting, Mnangagwa [12] on the previous day with captains of industry (mostly university graduates), the discussion was based on the skills gap which the participants promised to address by short courses and engaging university students for industrial attachments. The small and medium enterprises were encouraged to be in harmony with business regulations and be properly registered and proportional. The issue of developing university towns would improve the economy mobility base and the services will be developed to increase employment opportunities. By 2020 Zimbabwe was envisaged having decent jobs, no poverty and individuals will be self-reliant. The universities were tasked to be vehicles of this development. The diasporas were expected to come back and invest in Zimbabwe then partner with government ministries. The government has already ventured into making the country open for business for both locals and diasporas. Talent is being rewarded and the atmosphere was being created for investments and economic development.

Firstly, the head of state Mnangagwa [12] had shown compassion in the education conference by allowing people of different positions to have the right to speak and air their views, and perform tasks and speak so as to be heard. They were given the right to contribute their ideas and actively participated with freedom of speech about education issues [18]. The spaces in the conference were created for individuals to voice their ideas and all were mutually attuned to another. The government representatives and universities were helped to listen to students' ideas, problems and compliments. Even if they were critical of the system of education as they summarized their problems, their views got respected and were heard. The universities and students could connect with each other as they engaged through argument and narrative outcomes to bring about new initiatives. Love was displayed and it promotes critical learning, cultivation of sharing, knowledge and respect of each other's views which Waghid [18] calls DCE. In this kind of education learners and educators, and all stakeholders of education, friendship creation is engaged in and individuals can risk together and explore to enter into ventures seeming impossible. The government, universities, industry, students and graduates would work at venturing into avoiding injustice, violence and extremism in fighting against each other concerning the struggles they have faced over the years leading to the high rate of unemployment of graduates. Instead all choose to deliberate with tolerance, friendliness and compassion respecting and forgiving each other in order to promote DCE in universities.

The environment created in the education conference helped all individuals to freely express themselves on how they feel with education that does not earn them jobs. Critical thinking through the speeches gets cultivated. Surely they would not be critical thinkers if their learning did not contribute to their advocating for a just a world with reduced or no poverty, no dictatorship and no corruption. The participants needed to champion their right to employment and the employed need to be responsible for meeting the needs of the job-less. All should treat each other as friends who respect and also feel respected even when they are either employed or unemployed. This cultivates individuals' need to critically discuss and query each other's experiences by asking how and why one is either employed, unemployed or under employed. This kind of friendship would be developed overtime as friends learn to take risks, engage in debates, respect and forgive one another. The individuals would realize they are different in their thinking and perception when they get aware of the risks involved in business ventures. Others become vulnerable to circumstances and situations beyond their control, encounter problems in the process for compassion to be practical to develop and create friendships. The steps to these are respected and forgiveness and individuals learn to engage each other, as a result DCE gets realized.

This promotion of stakeholder involvement helps to enhance democracy since people want to be seen as participants in dialogue [18]. The issue here is that people are encouraged to be willing to be listening to what others say. In turn they learn to respect their worth even if they do not agree with them. They learn to forgive, respect and move on trusting. They too have meaningful contributions as rational beings and sources of value. The teaching is that people should avoid ripping off each other's ideas, to never bribe or manipulate but only criticize when necessary. The people, government and universities in their respect should respectfully appreciate different values found in others. People should avoid excluding other systems, universities and industry but should learn to forgive even if they disagree, should agree to disagree but engage in tolerance and constructive interaction and deliberation. Engaging in a process of reaching a stage of democracy helps individuals to reach a stage of irresolvable moral conflict [18]. For example, the gap between graduation and industry requires universities, government and industrialists to forgive one another and show respect. All need to respect the demands each has. The gap between graduation and industry is an irresolvable conflict thus needs further research. All key players and stakeholders in education and industry need to excuse each other from rigour, honour and other but should be free to challenge each other with respect handling criticism of policy initiatives with due care. Education policies can either be OK or not $\mathrm{OK}$ in cases where curriculum innovations get imposed in universities. Educators would need to do a self-reflection and critique in implementing policy and should have freedom to say 
yes or no to issues and yet had respect for their choices.

\subsection{Concluding Remarks}

In conclusion, it can be noted that the issue of graduate employability of democratic citizens becomes a matter of concern. Graduates will be expected to have sustained participation and engagement in the industry as employees or as entrepreneurs and job creators. On the other hand, the demand for universities and educators to provide democratic citizens ready to meet the demands of the market creates a great competition in universities and the market place. This puts a lot of pressure for universities. More problems end up emerging resulting in pressure in conformity and lack of creativity in basic research and, of course, competition is encouraged in universities and the industry. Universities are expected to produce graduates that are well equipped with skills and all qualities needed for them to participate in their communities as democratic citizens who would contribute and work as professionals for economic and personal development. The next section discusses the findings of the study.

\section{Data Presentation, Analysis and Interpretation of Findings}

This section was based on the objective that guided the paper which was to identify and examine the effects of the stakeholder involvement as a democratic effort to link university education to industry expectations. The research question was to measure to what extent the stakeholder involvement achieved democracy as an effort to link university education to industry expectations in issues of employability. This section sought to present, analyze and interpret the responses to following interview questions:

Question 1: How does the industry engage universities in their approach to promote employability?

Question 2: $\quad$ How are stakeholders involved in the production of quality education?

Question 3: Who should be involved in the development of educational policy in Zimbabwe?

\subsection{Results}

The results are presented basing on answers of the interview questions in the section that follows.

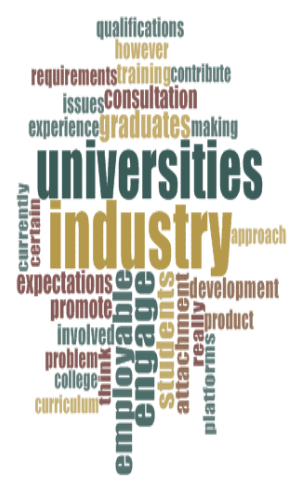

Figure 1. How Industries Engage Universities to Promote Employability Source: Research Results (2018)

Figure 1 represents a word cloud that confirms text search query results to show how industry engages universities to promote employability and the involvement of stakeholders. There has been notable high and low engagement, less or no consultation of stakeholders concerning the issues of curriculum development. The universities and industries have come together when it came to student industrial attachment.

Table 1. How Industries Engage Universities to Promote Employability

\begin{tabular}{|l|c|l|}
\hline NVivo Node & \multicolumn{1}{c|}{$\begin{array}{l}\text { Number of } \\
\text { Coding } \\
\text { References }\end{array}$} & $\begin{array}{l}\text { Coding } \\
\text { Reference } \\
\text { Percentage }\end{array}$ \\
\hline $\begin{array}{l}\text { No Meaningful } \\
\text { Engagement }\end{array}$ & 8 & 32 \\
\hline $\begin{array}{l}\text { Curriculum } \\
\text { Development } \\
\text { Involvement }\end{array}$ & 9 & 36 \\
\hline Internship & 5 & 20 \\
\hline $\begin{array}{l}\text { Governance- } \\
\text { Involvement in } \\
\text { University } \\
\text { Councils }\end{array}$ & 1 & 4 \\
\hline Career Fairs & 2 & 8 \\
\hline
\end{tabular}

Source: Research Results (2018)

The picture of results accounted for in Table 1 is about how industries engage universities in the approach to promote employability. Eight out of 20 respondents cite that there is no meaningful engagement. Nine reveal that there is more of curriculum development involvement, five of them show that industries are only involved in providing 
internships and one participant spoke about governance, whereby, the involvement of industries is only in university councils. Table 1 provides a summation in the percentages showing that the majority of the participants believe that in order for industries to promote employability, they engage universities more in issues of curriculum development followed by $20 \%$ of internships. These are instances when university students are engaged in industrial attachment.

The contradiction by the $32 \%$ of the targeted population is seen in those who say that there is a limited engagement because of the top down approach and there is no consultation by policy makers to relevant stakeholders. This ends up affecting the working together of universities and industries in order to produce employable graduates who are job creaters and are productive entrepreneurs. Out of a population of 20 only two respondents forming a $8 \%$ of the population as presented in Table 1 spoke of the involvement in career fairs. Involvement is expected to be high in career fairs between the industries and universities where students can be given career guidance. The industries and universities could come up with ways of making the students self-reliant, employable and also become job creators.

The emphasis is on consultation and expectation of high engagement of industries and universities. The universities could engage the industry boards in dialogue in order to ask about the needs of industries. The industry system in Zimbabwe has been paralyzed and there has been no fruitful implementation since most industries are closing down due to the harsh economic crisis. However, with all efforts the country is doing, there is hope that there would be a great change and restoration in the economy. The universities could create think tanks from industry who advice on new developments that should be addressed through college degrees. Industry should be part of the graduate-making process. The managers should contribute in the drawing up of education policies with the emphasis on meeting the requirements or expectations of their industries in terms of performance.

This concurs with literature in a review of graduate employability by Lowden et al. [8], Makoshori [9] who concluded that the problem with the issue of employability is that there is always a discrepancy between what academics view higher education institutions are for, and how the government views the institutions. The employers and higher education institutions always have a different understanding of employability and the concept of relevant skill. The employers see graduate attributes as more important than the degree subjects and this affects the progress in promoting graduate employability measures Lowden, et al. [8] and Garwe [5]. Many of the education strategies are made in order to ensure that the economy is stabilized. New jobs are being added as long as the strategies are implemented appropriately in order to get the graduates involved in job-creating activities. The efforts in Zimbabwe for such an opportunity to create jobs have not been that fruitful since the unemployment rate has remained high over a period of time.

The ideas are also supported by the studies carried out by Mawere [11] who reveals that some policies are only in favour of those that are still in universities without considering what will happen to them when they graduate and are expected to be absorbed into the industry. Full engagement and consultation between industries and universities would be very essential at such a stage to come up with ways of assisting the students so that they get groomed to be employable later and also become good and productive and selfreliant job creators and entrepreneurs (Mawere [11], Shizha and Kariwo [14]).

On the other hand, when policy strategies for job creation are suggested well through proper consultation with relevant stakeholders, the industries and universities involved, can be in favour of the graduates. One of the strategies suggested would be putting into place a policy whereby a job is created without displacing any economic activity. Such kinds of policy strategies are made in favour of graduates so that as they graduate they have employment opportunities. Many of the strategies made are to make sure that the economy is stabilized and new jobs are being added as long as the strategies are implemented appropriately in order to get the graduates involved in job-creating activities.

Figure 2 visually show that 10 out of the 20 respondents reveal that stakeholders have a limited involvement in the production of quality education. They agree that it can be very difficult for stakeholders outside of education field to influence quality. Yet if they work together, they would offer better quality education through the synergy. The six of the consultants as in Figure 2 mean that stakeholders offered advisory support services. They mention that lecturers, industry players and other stakeholders are given a chance to form committees that often meet to create education policies. These respondents also mention the meeting together of law societies in Zimbabwe who engage the Faculty of Law at different universities. The Zimbabwean institution of engineers also campaigns for engineering graduates to be offered advisory support about curriculum issues. Respondents go further by encouraging universities to use Triple Helix theory, a tripartite involvement of government, universities and industry.

The responses above are collaborated in literature by Vaivode [17] who agree that the Triple Helix model assumes that the production and dissemination of socially organized knowledge drives economic development in a country. The institutions are encouraged to play a role of networking the relations 
among the key actors: universities, industries and the government.

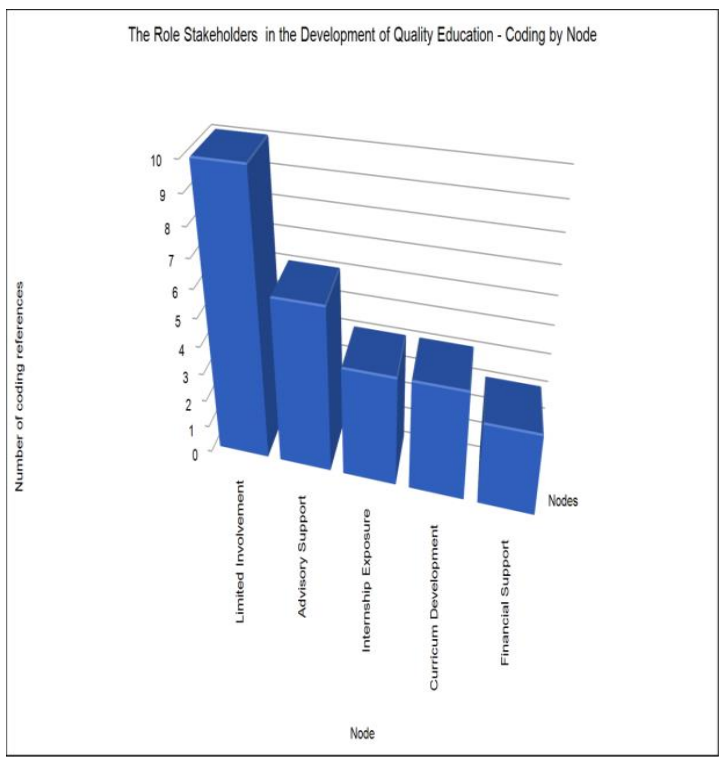

Figure 2. Role of Stakeholders involved in Development of Quality Education Source: Research Results (2018)

The writer Vaivode [17] see the purpose of innovation policy as to select a desirable future and facilitate its realization. Innovation is defined as what comes out when science, technology, and innovation have a common linkage. Policy planners, therefore, need to involve all stakeholders in order to get involvement of all relevant key players. In this instance the universities, industries and the government are key players. The universities, of, course would require the involvement of parents, teachers, students, etc. If all key players get involved and come up with basic innovations having entrepreneurship is the driving force of innovations, for the education policies, Zimbabwe can be assured of economic growth, welfare and the improved standard of living of the citizens.

On the other hand, there are four respondents out of 20 who said that stakeholders are involved in internship exposure for students. The other four respondents reveal that stakeholders are involved in curriculum development, whereas three reveal that they offer financial support services. Although all stakeholders may want to be involved in the production of quality education, not all of them are involved in decision-making. Only administrators, teachers and elected officials such as the school board are involved in the production of quality education. Also some stakeholders are involved in the production of quality education by financing some of the students undergoing industrial attachment. Some train the students during the industrial attachment period. The emphasis is that industries are very active because they take interns for the practical aspect and to help them gain the exposure on particular fields under studied by students. When students get attached in the industries, the industries also give feedback on their performance to universities and get involved in the designing of the curriculum.

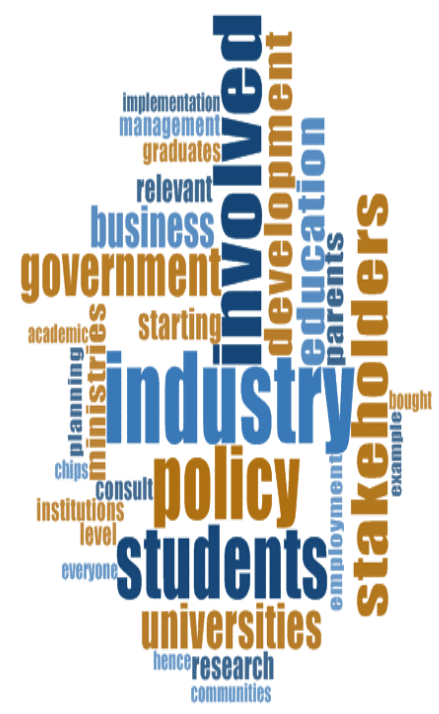

Figure 3: Who should be Involved in Development of Educational Policy

Source: Research Results (2018)

Figure 3 visually represented the key players that the respondents thought should be involved in policy planning and development and the general answer was that everyone was to be involved in policy planning and development. A list that was given in Figure 3 included the following: students, industrialists, curriculum planners and innovators, parents and the community, and government officials. Clearly, all students, industrialists, curriculum planners and innovators, government officials, parents and the community should be involved in policy issues. The list also included the politicians, Members of Parliament, chief executives and senior administrators, influential people in national associations representing various interest groups, Employers Associations, Chambers of Commerce and Trade Unions and the researchers from universities or other tertiary institutions.

The analysis bar chart in Figure 4 provides a beautiful summation of the comparatives and the coding references in numbers and percentages. Out of the 20 respondents 14 of them forming $20.9 \%$ of the targeted population site that universities and industries should be more involved in the planning and development of educational policy. Eleven respondents were saying that all stakeholders including the government should be involved in development of educational policy in Zimbabwe. 
Who Should be Involved in the Development of Educational Policy in Zimbabwe - Coding by Node

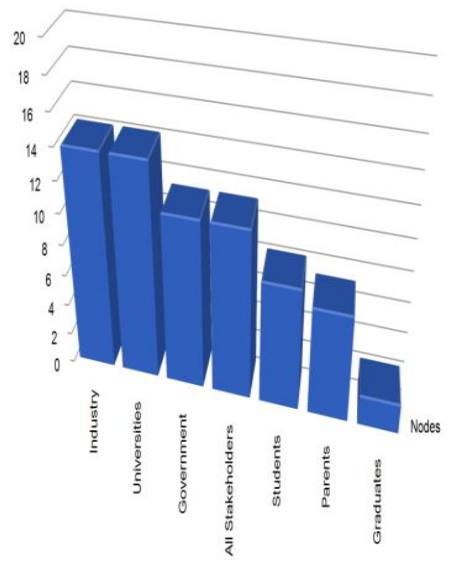

Node

Figure 4: Who should be Involved in Development of Educational Policy

Source: Research Results (2018)

The eight spoke about students, seven mention parents and only two out of the 20 respondents see graduates' involvement in planning and development of educational policy key. The relevant ministries should be involved in the development of policy and need to do that with relevant stakeholders. The importance of collaboration and involvement of many players in policy planning and development is upheld by Waghid [18] and Vaivode [17]. The weight is given to all stakeholders but more weight seems to hinge on government, universities and industry.

In his writing, Garwe [5] collected the opinions of the parents and the community concerning an important observation that massive education in Zimbabwe led to huge investments into education. This led to a decline in public funding, hyperinflation and economic mismanagement. The highly educated labour amongst the parents and community population were also heard demanding high salaries and incentives as cited by Mawere [11]. All these cries from students, parents and community if considered by policy planners would assist in coming up with strategies on how to handle the education and training challenges and barriers and work together towards bringing solutions. In agreement, Waghid and Davids [18] promote partnership of key players in order to bring lasting change. A creation of universities where cosmopolitanism is a virtue to be taught in universities in order to eradicate political dictatorship and mass enslavement is created. In such a scenario friendship is developed and an experience of freedom and quality is created as ideas are being suggested. Different stakeholders get to contribute to stabilizing the economy and adding new jobs, if ideas are implemented appropriately. Universities can form partnerships with private colleges and other universities, businesses, and civil society organizations. By tailoring curricula and training programmes to local market needs, African higher education institutions, and of course, Zimbabwean institutions included, can develop new funding streams and respond directly to the unemployment problem [14].

\section{Conclusions}

Since curriculum content is key in developing attributes of graduates, Zimbabwe is encouraged to promote democracy in education by involving all stakeholders in planning and development of programmes in order to produce graduates that are employable. The emphasis is on creating democratic education and contributing to making Zimbabwean education democratic, fair, equitable, non-racial and non-sexist. Zimbabwe needs to achieve fairness and equity in education.

\section{Recommendations}

1. Universities should re-engage industry and other stakeholders so as to redesign curricular that will solve problems and bring a lasting change. The universities will then categorize their programmes according to the critical manpower shortage areas. The companies in turn should be informed to provide feedback in scientific and technological requirements of industry and commerce and assess programmes to ensure the right skills are imparted. The employability skills can be placed at the centre of organizations' strategic plans. Access to work placements needs to be widened.

2. It is highly recommended that the government, ministries and universities partner with each other and all stake holders in education policy issues. Parents, teachers, principals, community advocates, business leaders, community agencies and general citizens should become active partners. Engaging in such a collaborative process would bring lasting change. Proposals that are made need to be followed and continuous stakeholder consultation should never wait for a crisis. The voices of all stakeholders need to be heard.

\section{Conclusion}

The hope is that the government, universities and industries with all relevant stakeholders would have constructive consultations and be able to come up with new education policies and new reforms that will bring a renaissance in the Zimbabwean economy. The 
leaders would be in a position to listen to every voice of the people, juggle around all voices then present alternative viewpoints amicably and change would be managed appropriately. The different stakeholders' contributions in education and economic policy issues are expected to produce new language, posture, position and direction that Zimbabwe could take to stabilize the economy. A new stable season would be marked. This would be a season when values are corrected and projected towards economic recovery, industrialization of the economy and creation of employment.

\section{References}

[1] Beck, J. S. (2010). Cognitive Therapy, Accessed from http://onlinelibrary.wiley.com/doi/10.1002/978047047921 6.corpsy0198/abstract on 2 July 2017.

[2] Cherry, K. (2014). What Is Basic Research? http://psychology.about.com/od/bindex/g/basicres.htm. Accessed on 25 Nov 2015.

[3] Creswell, J. W. (2009). Research Design: Qualitative, Quantitative and Mixed Methods Approaches. London: Sage Publications. 1-235.

[4] Denscombe, M. (2010). The Good Research Guide: For Small Scale Social Research Projects. (4th Ed.). New York: McGraw Hill, Open University Press.

[5] Garwe, E. C. (2015). Holistic Initiatives for Enhancing Graduate Employability in Zimbabwe, Zimbabwe: Zimbabwe Council for Higher Education.

[6] Grady, M. P. (2016). Qualitative and Action Research: A Practitioner Handbook. USA: Phi Delta Kappa Educational Foundation.

[7] Gray, D. E. (2014). Doing Research Research in the Real World, London, Sage.

[8] Lowden, K. et al. (2011). Employers Perceptions of the Employability Skills of New Graduates: Research Commissioned by the Edge. London: University of Glasgow.

[9] Makoshori, S. (2017). Financial Gazette "Workers Toil for Nothing". Accessed from: www.financial gazette.co.zw on 30 March 2017.

[10] Mason, J. \& Dale, A. (2010). Understanding Social Research: Thinking Creatively about Method. London: Sage.

[11] Mawere, D. (2013). Evaluation of the Nziramasanga Report of Inquiry into Education in Zimbabwe 1999: The Case of Gender - Equality in Education, International Journal of Asian Social Science, Gweru. 6-12.

[12] Mnangagwa, E. D. (2018). President with University Chancellors and Students, Zimbabwe. Accessed from: www.financial gazette.co.zw on 9 January 2018.
[13] Murwira, (2018). Speech on Universities. Accessed from: Zimbabwe Broadcasting Cooperation on 21 February 2018, 2100 hours

[14] Shizha, E. \& Kariwo, M. T. (2011). Education and Development in Zimbabwe: A Social, Political and Economic Analysis. Boston: Sense Publishers. 3-124.

[15] Van Der Wal DM, M. GA. (2015). Differentiating between Descriptive and Interpretive Phenomenological Research Approaches: Nurse Researcher, Pretoria, South Africa: UNISA.

[16] Van Manen, M. (2011). Orientations in Phenomenology. Accessed from: tinyuri.com/px7a2ms on 20 March 2017).

[17] Vaivode, I, (2015). Triple Helix Model of UniversityIndustry-Government Cooperation in the Context of Uncertainties, Available online at www.sciencedirect.com Science Direct (last accessed on 20 November 2017).

[18] Waghid, Y. (2010). Challenges for Higher Education in Africa, Ubuntu and Democratic Justice. In Calhoun, C. $\&$ Rhoten, D. (eds), New Trends in Higher Education. New York: Social Sciences Research Council, on invitation.

[19] Waghid, Y. (2014). Pedagogy Out of Bounds: Untamed Variations of Democratic Education. Boston: Sense Publishers.

[20] Waghid, Y. \& Davids, N. (2018). (eds), African Democratic Citizenship Education Revisited: Palgrave Studies in Global Citizenship Education and Democracy, Switzerland: Pangrave Macmillan/Springer International Publishing AG. 